\title{
PCR-SSCP of the 16S rRNA gene, a simple methodology for species identification of fish eggs and larvae
}

\author{
EVA GARCÍA-VÁZQUEZ ${ }^{1}$, PAULA ÁLVAREZ ${ }^{2}$, PLACIDA LOPES $^{3}$, \\ NIKOLETTA KARAISKOU ${ }^{4}$, JULIANA PÉREZ ${ }^{1}$, ANA TEIA ${ }^{3}$, JOSÉ L. MARTÍNEZ ${ }^{1}$, \\ LAURENTINA GOMES ${ }^{3}$ and COSTAS TRIANTAPHYLLIDIS ${ }^{4}$ \\ ${ }^{1}$ Departamento Biología Funcional, Universidad de Oviedo. C/ Julián Claveria s/n 33006-Oviedo, Spain. \\ E-mail: egv@fq.uniovi.es \\ ${ }^{2}$ Fundación AZTI. Departamento de Recursos Pesqueros. Herrera kaia portualdea z/g. 20110 Pasaia (Guipúzcoa), Spain. \\ ${ }^{3}$ Instituto de Investigaçao das Pescas e do Mar. Avda. de Brasilia 1449-006 Lisbon, Portugal. \\ ${ }^{4}$ Department of Genetics, Development and Molecular Biology, School of Biology, Aristotle University of \\ Thessaloniki, 54124 Thessaloniki, Macedonia, Greece.
}

\begin{abstract}
SUMMARY: Patterns of the 16S rRNA gene obtained in 8 and 12\% acrylamide gels by the SSCP (Single Strand Conformation Polymorphism) method were different for various marine fish species (Macrorhamphosus scolopax, Scomber scombrus, Lepidorhombus boscii, L. whiffiagonis, Trachurus trachurus, T. mediterraneus, Molva molva, Merluccius merluccius). SSCP patterns of this gene were employed to successfully identify formaldehyde-fixed eggs of different species (Merluccius merluccius, Scomber scombrus, Macrorhamphosus scolopax and L. whiffiagonis) in plankton samples. The advantages of SSCPs in comparison with current genetic methods of egg identification are based on their technical simplicity and low price. The application of the PCR-SSCP methodology is proposed for routine genetic analyses in plankton surveys.
\end{abstract}

Keywords: fish species, genetic markers, ichthyoplankton, mitochondrial genes, PCR-SSCP.

RESUMEN: PCR-SSCP DEL GEN 16S RRNA, UN MARCADOR MOLECULAR PARA IDENTIFICAR HUEVOS Y LARVAS DE PECES. - LOS patrones SSCP (Polimorfismo para la Conformación de Cadena Sencilla) obtenidos para el gen 16S rRNA en geles de acrilamida al $8 \%$ y al $12 \%$ fueron diferentes para diversas especies piscícolas marinas (Macrorhamphosus scolopax, Scomber scombrus, Lepidorhombus boscii, L. whiffiagonis, Trachurus trachurus, T. mediterraneus, Molva molva, Merluccius merluccius). Los patrones SSCP de este gen fueron empleados con éxito para la identificación de huevos de distintas especies (Merluccius merluccius, Scomber scombrus, Macrorhamphosus scolopax y L. whiffiagonis) fijados en formaldehído, obtenidos de muestras de plancton. Las ventajas de los SSCPs respecto a las metodologías genéticas existentes actualmente para identificación de huevos de peces en plancton se basan en su sencillez y bajo coste. Se propone la aplicación de metodología PCR-SSCP para el análisis genético rutinario de muestras de plancton.

Palabras clave: especies piscícolas, marcadores genéticos, ictioplancton, genes mitocondriales, PCR-SSCP.

\section{INTRODUCTION}

Egg identification in plankton samples is necessary for purposes of stock assessment (Pérez et al., 2005). At sea, plankton is sampled and normally preserved in formaldehyde to avoid shape and colour changes that may complicate the visual inspection of eggs to determine their developmental stage. The eggs of many marine fish species are morphologically very similar (Moser et al., 1984). 
Species determination by visual inspection, generally based on diameter, colour, shape and oil globule, is thus very difficult. For example, eggs of European hake Merluccius merluccius and the megrims Lepidorhombus whiffiagonis and L. boscii overlap in size (egg diameter of 0.94-1.03 for Merluccius merluccius and 1.02-1.22 for both megrims), exhibit similar colour (transparent) and shape (spherical), and have one oil globule of $0.27 \mathrm{~mm}$ of diameter (on average). Misidentification of ichthyoplankton based on visual inspection has been recently reported (Pérez et al., 2005). Instead, species-specific genetic markers allow accurate identification of eggs. Initial visual sorting is necessary to separate fish eggs from the rest of the plankton specimens. Then, eggs can be separately inspected to determine their developmental stage and other characteristics of interest before squashing, DNA extraction and genetic species determination. DNA-based methods are the most useful tool for identifying marine organisms (Sweijd et al., 2000; Feral, 2002; Shao et al., 2002).

The first issue to be considered when one is developing species-specific markers is the type of marker to be employed. Target sequences are mitochondrial genes (Medeiros-Bergen et al., 1995; DeSalle and Birstein, 1996; Palumbi and Cipriano, 1998; Taylor et al., 2002) because their large number of copies per cell enables PCR amplification even in early developmental stages when the number of cells per egg is small. On the other hand, sequences must be conserved within species and variable between species. Highly conserved coding genes such as ribosomal DNA are thus the first choice.

There are different methods for visualising genotypes. Some automated or semi-automated protocols, such as Taq-Man, require sophisticated equipment and technological training of the experts in charge of typing (Taylor et al., 2002). Other cheap methods have been used to identify fish species, such as PCR followed by fragment size identification in agarose or acrylamide gels (Perez and Garcia-Vazquez, 2004), which can be applied by technicians without very specialised skills. Although the ideal method depends on the needs and available resources of the user, an easy and cheap methodology based on simple equipment is often needed for routine analyses.

The SSCP (single-stranded conformation polymorphism) method offers a sensitive but inexpensive and rapid method for determining differences in sequence in DNA samples. A major advantage of using this methodology is that no previous knowledge of the DNA sequence is needed, and different DNA sources from the same sample can be discriminated (Sunnucks et al., 2000). It has been widely applied in biomedical research (see a review in Hayashi and Yandell, 1993) and in population biology (Hedrick et al., 1999; Congdom et al., 2000; Small and Gosling, 2000; D'Urso et al., 2003). The range of topics studied employing SSCP to detect sequence variation is very wide, from intraspecific variation at population level (Taylor et al., 1999) to bacterial diversity (Schmalenberger and Tebbe, 2003). Species identification has been achieved using the SSCP method in aphids (Wilson et al., 1999; Sunnucks et al., 2000). As it is easy and inexpensive, this method can be considered for routine surveys of large sample sizes (Sunnucks et al., 2000).

This study aimed to analyse the usefulness of the SSCP method by employing the 16S rRNA gene as a genetic marker for species identification of marine fish eggs stored in $4 \%$ formaldehyde (the most common fixative employed for preservation of specimens in plankton surveys). The work was based on the discrimination between eggs of European hake (Merluccius merluccius) and megrims (Lepidorhombus boscii and L. whiffiagonis), currently possible only by PCR-fragment size determination in an automated sequencer (Perez et al., 2005). The advantages and disadvantages of these methods are discussed.

\section{MATERIALS AND METHODS}

\section{Biological samples}

To explore the potential utility of this method for specific identification of fish eggs from preserved plankton samples, 50 adult samples from eleven species of commercial interest were obtained from different Atlantic areas. These species were: Lepidorhombus boscii, L. whiffiagonis, Merluccius merluccius, Macrorhamphosus scolopax, Scomber scombrus, Trachurus trachurus, Merlangius merlangus, Molva molva, Pollachius virens, Pollachius pollachius and Gadus morhua. Tissue samples (gills or muscle) from adults caught in different areas of the distribution of these species were obtained and ethanolpreserved for further analysis. 
A batch containing some formaldehyde-preserved eggs visually sorted from different plankton samples of the Bay of Biscay was prepared. The plankton samples were obtained employing bongo nets (60 $\mathrm{cm}$ diameter, $303 \mu \mathrm{m} \mathrm{mesh}$ ) towed to a nominal depth of 200 metres, and retrieved obliquely. Fish eggs at each tow were manually sorted before the ship departed from the sampling station, then fixed in $4 \%$ buffered formaldehyde solution $(\mathrm{pH}=7.5)$. The plankton sampling was carried out in the ICES VIIIc area (Bay of Biscay) in 2002. The eggs were preserved in the formalin solution for more than one year until January 2004, when laboratory analyses were carried out.

In order to compare this method with others currently available for fish egg identification (PCR amplification + fragment size determination in an automated sequencer; see Pérez et al., 2005), additional adult samples of Merluccius merluccius, Lepidorhombus whiffiagonis and L. boscii (Table 1, Fig. 1) were analysed by PCR-SSCP to test speciesspecificity of the patterns obtained. SSCP patterns of eggs fixed in ethanol were compared with those obtained from eggs of the same species fixed in for-

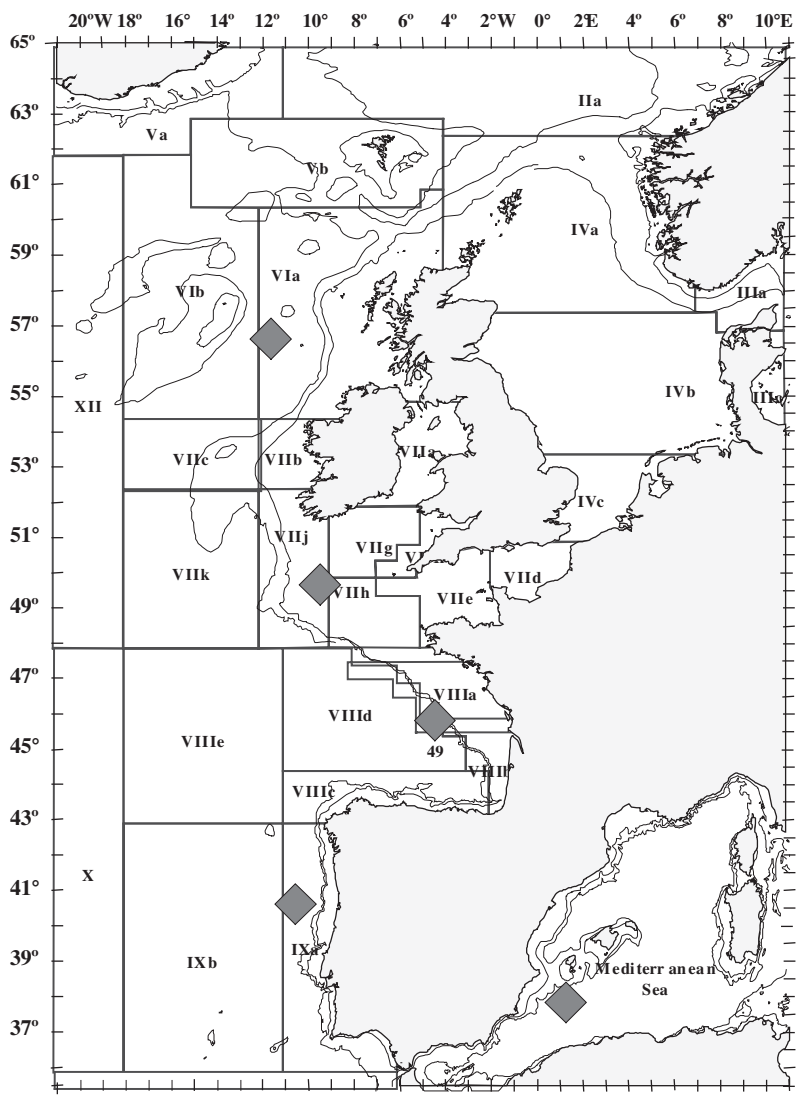

FIG. 1. - Map showing sampling areas (diamonds).
TABLE 1. - Number and origin of the adult individuals analysed

\begin{tabular}{lcc}
\hline Species & Area & Number \\
\hline \multirow{2}{*}{ Merluccius merluccius } & ICES VI & 20 \\
& ICES VII & 20 \\
& ICES VIII & 20 \\
& ICES IX & 20 \\
& Aegean Sea & 20 \\
& TOTAL & 100 \\
Lepidorhombus boscii & ICES VII & 20 \\
& ICES VIII & 20 \\
& ICES IX & 20 \\
& Aegean Sea & 20 \\
& TOTAL & 80 \\
Lepidorhombus whiffiagonis & ICES VI & 20 \\
& ICES VII & 20 \\
& ICES VIII & 20 \\
& Spanish Mediterranean coast & 20 \\
& TOTAL & 80 \\
& &
\end{tabular}

malin. Megrim (Lepidorhombus whiffiagonis) eggs were obtained by artificial fertilisation of mature males and females caught in the ICES VIa area in a commercial vessel, and fixed in ethanol (50\% eggs) or $4 \%$ formaldehyde buffered with sodium tetraborate (50\% eggs) 24 hours after fertilisation. We analysed 30 ethanol-fixed and 30 formaldehydefixed eggs one year after fixation.

More details on plankton sampling and fertilisation experiments can be found in Pérez et al. (2005).

\section{DNA extraction}

DNA was extracted from ethanol-preserved adult samples following the Chelex-based protocol described by Estoup et al. (1996). From individual eggs, DNA was extracted using the QIAamp MiniKit DNA tissue Kit (QIAGEN). The formalinfixed eggs were washed with PBS to remove the formalin prior to following the standard QIAGEN protocol. The extracted volume of eluted DNA was $200 \mu \mathrm{l}$ for adults and eggs, performed in two $100 \mu \mathrm{l}$ elution steps.

\section{PCR-SSCP protocol}

PCR amplification of the mitochondrial 16S rRNA gene segment (564-568 pb long) was performed using the primers $\mathrm{H}_{3080}$ (5'-CCGGTCTGAACTCAGATCACGT-3') and $\mathrm{L}_{2510}$ (5'-CGCCTGTTTATCAAAAACAT-3') described in Palumbi et al. (1991). The reaction was carried out in a total volume of $20 \mu \mathrm{l}$ including $1.5 \mathrm{mM} \mathrm{MgCl}, 0.25 \mathrm{mM}$ dNTPs, 20 pmol of each primer, $20 \mathrm{ng}$ of template 
DNA and $1 \mathrm{U}$ of DNA Taq polymerase (Gibco). The thermocycler conditions for the amplification were the following: an initial denaturing step at $95^{\circ} \mathrm{C}$ for $5 \mathrm{~min}$, then 30 cycles of $95^{\circ} \mathrm{C}$ for $20 \mathrm{~s}$, annealing at $48^{\circ} \mathrm{C}$ for $20 \mathrm{~s}$ and $72^{\circ} \mathrm{C}$ for $20 \mathrm{~s}$, and one extension at $72^{\circ} \mathrm{C}$ for $7 \mathrm{~min}$.

$10 \mu \mathrm{l}$ of the PCR product were denatured at $95^{\circ} \mathrm{C}$ for $5 \mathrm{~min}$, then loaded in a $8 \%$ or $12 \%$ acrylamide gel (acrylamide/bisacrylamide 50:1) and run in a vertical electrophoresis apparatus at $80 \mathrm{~V}$ and $4^{\circ} \mathrm{C}$ for $4 \mathrm{~h}$. Then the gel was fixed in $10 \%$ ethanol for 8 min, oxidated in $1 \% \mathrm{HNO}_{3}$ for $3 \mathrm{~min}$, washed twice in MilliQ water, stained in $\mathrm{AgNO}_{2}(2.02 \mathrm{~g} / \mathrm{l})$ for 20 min, washed twice in MilliQ water again and revealed in $29.6 \mathrm{~g} / 1 \mathrm{Na}_{2} \mathrm{Co}_{3}$ (anhydro) $+540 \mu \mathrm{l}$ of $37 \%$ formaldehyde. Revealing was stopped with $10 \%$ acetic acid for $5 \mathrm{~min}$, then the gel was washed in distilled water. SSCP variants were directly visualised in the gel. It is not useful to include standard size markers in the gel as references because in SSCP DNA chains are denaturalised and move differentially through the acrylamyde gel; differences in sequence, not in size, are detected.

In egg samples, PCR-SSCP was repeated at least twice in order to determine the reproducibility of the pattern obtained.

\section{DNA purification and 16S rDNA sequencing}

The amplified segment was sequenced for ten individuals of each SSCP variant found following the protocol described above. PCR products were visualised in $50 \mathrm{ml} \mathrm{1.5 \%}$ agarose gels with $3 \mu \mathrm{l}$ of $10 \mathrm{mg} / \mathrm{ml}$ ethidium bromide. Stained bands were excised from the gel and DNA was purified with an Eppendorf PerfectPrep Gel CleanUp Kit prior to sequencing. Automated fluorescence sequencing was performed on an ABI PRISM 3100 Genetic Analyser (Applied Biosystems) with the BigDye 3.1 Terminator system in the Unit of Genetic Analysis of the University of Oviedo (Spain). Both strands (direct and reverse) of each DNA fragment were sequenced.

\section{Sequence editing and analysis}

Mitochondrial 16S rRNA genes were edited using the BioEdit Sequence Alignment Editor software (Hall, 1999). Sequences were aligned with the ClustalW application (Thompson et al., 1994) included in BioEdit.
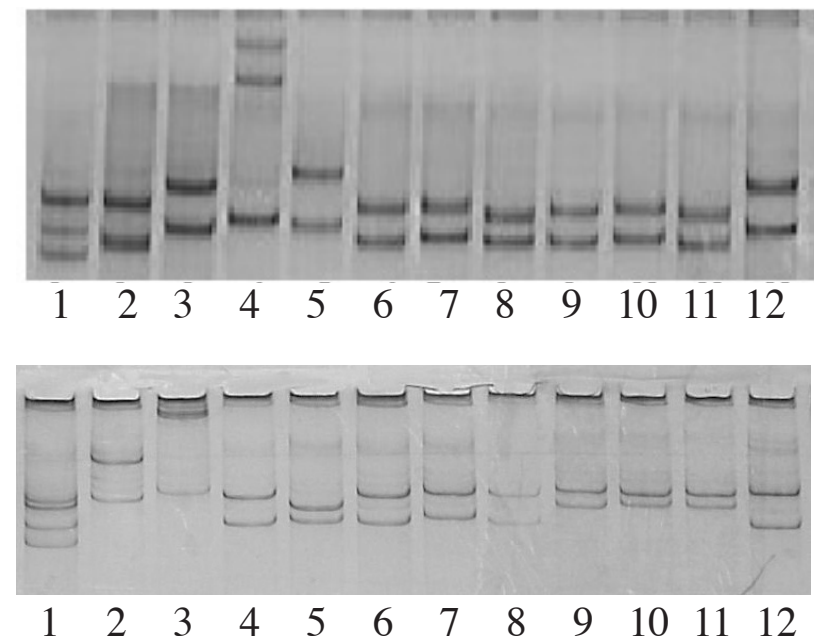

FIG. 2. - SSCP patterns obtained for 16S rRNA gene for different fish species, in gels with different acrylamide concentration. A) $8 \%$ acrylamide gel. From left to right: 1-11, control adults as following: 1, Macrorhamphosus scolopax, 2, Scomber scombrus, 3, Trachurus trachurus, 4, Lepidorhombus boscii, 5, L. whiffiagonis, 6, Merluccius merluccius, 7, Merlangius merlangus, 8, Molva molva, 9, Pollachius virens, 10, Pollachius pollachius, 11, Gadus morhua. 12 , formaldehyde-fixed egg. The SSCP pattern at the $16 \mathrm{~S}$ rRNA gene corresponds to the pattern of the control Trachurus trachurus. B) $12 \%$ acrylamide gel. From left to right: 1, Macrorhamphosus scolopax; 2, Lepidorhombus whiffiagonis; 3, L. boscii; 4, Melanogrammus aeglefinus; 5, Molva molva; 6, Pollachius pollachius; 7, P. virens; 8, Gadus morhua; 9, Trachurus mediterraneus; 10, T. trachurus; 11, egg of T. trachurus; 12, Merluccius merluccius.

\section{RESULTS}

Different patterns of bands were obtained for the eleven species considered in this study, allowing direct identification of some of them with the SSCP analysis of the 16S rRNA gene in both 8 and 12\% acrylamide gels (Fig. 2A and B respectively). For example, in $8 \%$ acrylamide gels (Fig. 2A) Macrorhamphosus scolopax (snipe fish) exhibited a three-band pattern clearly distinguishable from the rest of the species. The same can be applied to $L$. boscii, L. whiffiagonis, Merluccius merluccius, Scomber scombrus (mackerel) and Trachurus trachurus (horse-mackerel). The rest of the Gadoid species (Merlangius merlangus whiting, Molva molva ling, Pollachius pollachius pollack, $P$. virens pollock, and Gadus morhua cod), however, exhibited less marked differences in SSCP bands. In 12\% acrylamide gels it was also possible to distinguish Molva molva and Pollachius virens from other Gadidae species, as well as to differentiate Trachurus mediterraneus and T. trachurus.

Based on SSCP patterns, some eggs belonging to L. whiffiagonis, Macrorhamphosus scolopax, 
TABLE 2. - Egg identification in formaldehyde-fixed plankton samples obtained from the Bay of Biscay.

\begin{tabular}{lcc}
\hline $\mathrm{N}$ & Amplification & SSCP pattern \\
\hline 9 & Yes & Lepidorhombus whiffiagonis \\
43 & Yes & Macrorhamphosus scolopax \\
3 & Yes & Scomber scombrus \\
2 & Yes & Merluccius merluccius \\
9 & Yes & Unknown \\
6 & No & - \\
\hline
\end{tabular}

Scomber scombrus and Trachurus trachurus were identified in a batch prepared from plankton eggs sampled in the Bay of Biscay (Table 2). DNA amplification failed for six eggs (5.8\%) and 9 eggs (13\%) that exhibited unknown SSCP patterns.

In the extended study aimed to compare the SSCP method with that previously reported for egg identification of hake and megrims (PCR-fragment size determination), some intraspecific variation was found for megrims. The SSCP variants found for the 16S rRNA gene in adults of the three species considered are shown in Figure 3. A single pattern of two bands (A) was found for European hake Merluccius merluccius. Two variants were found for megrim Lepidorhombus whiffiagonis, one of two separate bands (B) and the other with a double and another single band $(\mathrm{C})$, found in individuals from the Mediterranean Sea. Five variants (D, E, F, G and $\mathrm{H})$ of different combinations of double and single bands were found for Lepidorhombus boscii in different areas of distribution of this species. The SSCP variants can be considered species-specific because all of them are particular to a single species. No one variant was shared by two species. The pattern A was exclusive of Merluccius merluccius, B and C of
Lepidorhombus whiffiagonis, D, E, F, G and H of $L$. boscii. As the samples analysed covered the whole distribution of the species, the results indicate that the $16 \mathrm{~S}$ rRNA gene SSCP can be employed as a species-specific molecular marker for identification of these species.

Sequences of the variants A (Merluccius merluccius), B (Lepidorhombus whiffiagonis) and D ( $L$. boscii) are in Table 3. These sequences have been included in the GenBank (Accession numbers DQ304654, DQ304653 and DQ304652, respective1y). For Lepidorhombus whiffiagonis, the differences between the variants $\mathrm{B}$ and $\mathrm{C}$ were due to an insertion of eight base pairs in position 350 in the variant C. For Lepidorhombus boscii, the differences between the SSCP variants were due to different combinations of the two substitutions and singlebase insertions along the fragment.

PCR amplification of the 16S rRNA gene was successful for $93.3 \%$ of both ethanol and formaldehyde-preserved megrim eggs. The patterns of bands obtained in ethanol-preserved, formaldehyde-preserved and adult megrims Lepidorhombus whiffiagonis are shown in Figure 4. The eggs showed a type $B$ variant, as expected from the origin of the spawning adults. The SSCP pattern obtained for eggs and adults was identical and very clear. The results were $100 \%$ reproducible in all cases. PCR-SSCP of the 16S rRNA gene can be employed for identification of hake and megrim eggs sampled in plankton surveys.

When the PCR-SSCP methodology is compared with that previously described for identification of formalin-fixed eggs in Pérez et al. (2005), some differences were found (Table 4). First, the equipment

Lepidorhombus boscii Lepidorhombus whiffiagonis

Merluccius merluccius

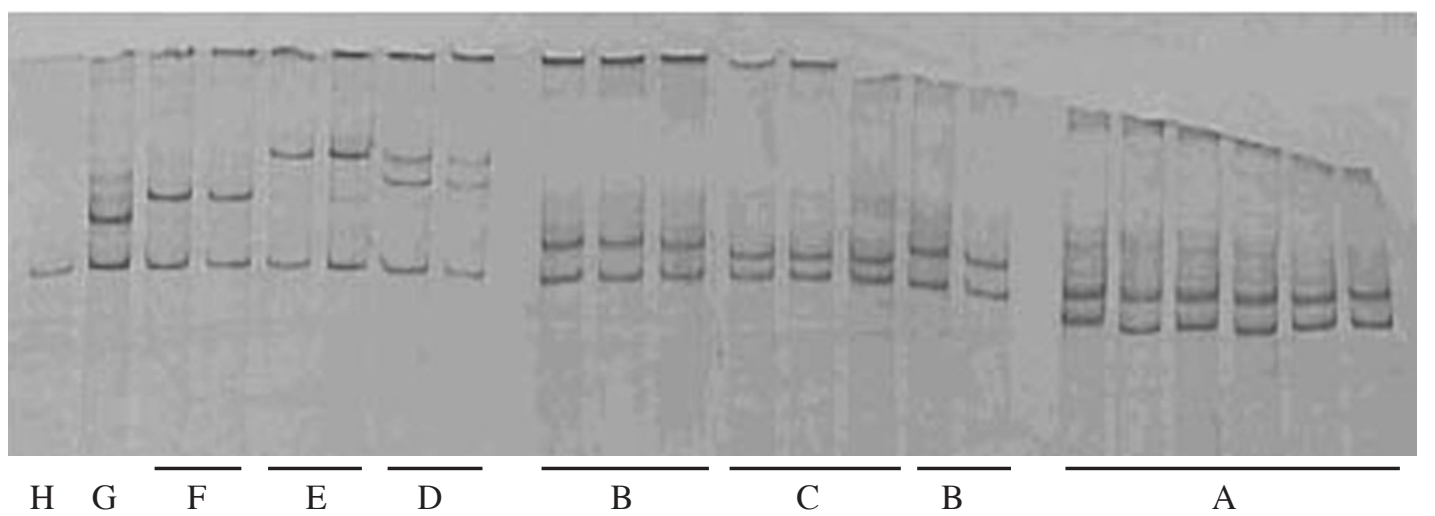

FIG. 3. - Acrylamide gel showing the SSCP variants found at the $16 \mathrm{~S}$ rRNA gene for Merluccius merluccius (variant A), Lepidorhombus whiffiagonis (variants B and C) and L. boscii (variants D, E, F, G and H). 
18 • E. GARCIA-VAZQUEZ et al.

TABLE 3. - 16S rRNA gene sequences of Lepidorhombus whiffiagonis (SSCP variant B, Lw), L. boscii (SSCP variant D, Lb) and Merluccius merluccius (SSCP variant A, Mm), aligned with the program CLUSTAL. The consensus sequence is marked with asterisks.

\begin{tabular}{|c|c|}
\hline $\begin{array}{l}\mathrm{Lw} \\
\mathrm{Lb} \\
\mathrm{Mm}\end{array}$ & 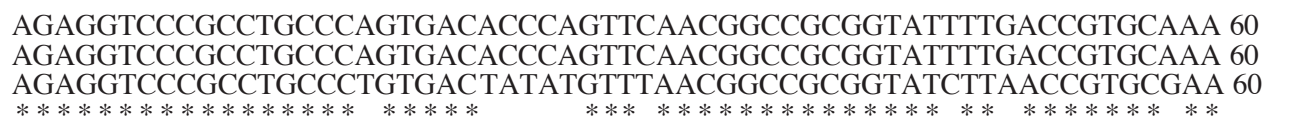 \\
\hline $\begin{array}{l}\mathrm{Lw} \\
\mathrm{Lb} \\
\mathrm{Mm}\end{array}$ & 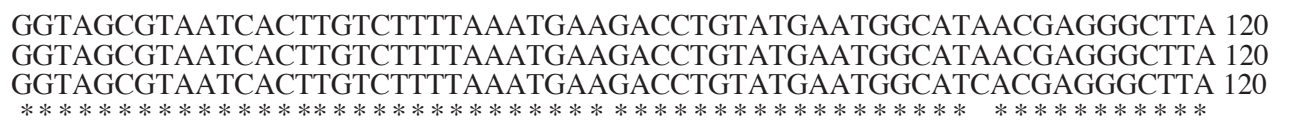 \\
\hline $\begin{array}{l}\mathrm{Lw} \\
\mathrm{Lb} \\
\mathrm{Mm}\end{array}$ & 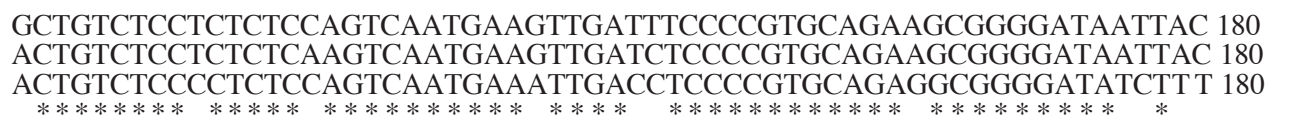 \\
\hline $\begin{array}{l}\mathrm{Lw} \\
\mathrm{Lb} \\
\mathrm{Mm}\end{array}$ & 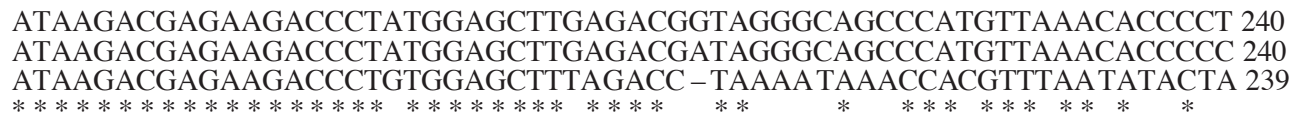 \\
\hline $\begin{array}{l}\mathrm{Lw} \\
\mathrm{Lb} \\
\mathrm{Mm}\end{array}$ & 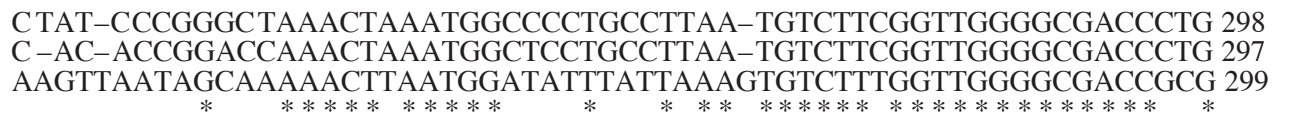 \\
\hline $\begin{array}{l}\mathrm{Lw} \\
\mathrm{Lb} \\
\mathrm{Mm}\end{array}$ & 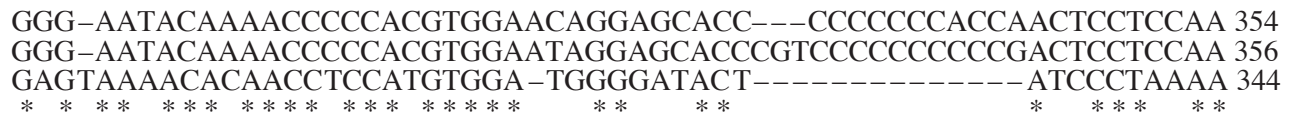 \\
\hline $\begin{array}{l}\mathrm{Lw} \\
\mathrm{Lb} \\
\mathrm{Mm}\end{array}$ & 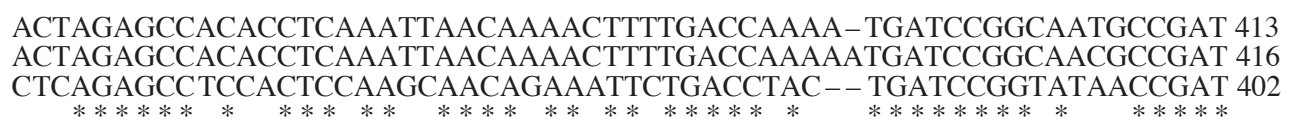 \\
\hline $\begin{array}{l}\mathrm{Lw} \\
\mathrm{Lb} \\
\mathrm{Mm}\end{array}$ & $\begin{array}{l}\text { CAACGGACCAAGTTACCCTAGGG-ATAACAGCGCAATCCCCTTTT-AGAGCCCATATCGA } 471 \\
\text { CAACGGACCAAGTTACCCTAGGGGATAACAGCGCAATCCCCTTTTAGAGCCCATATCGA } 476 \\
\text { TAACGAACCCAGTTACCCCAGGG-ATAACAGCGCAATCCCCTCTC-AGAGCTCATATCGA } 460 \\
* * * * * * * * * * * * * * * * * * * * * * * * * * * * * * * * * * * * * * * * * * * * * * * * * *)\end{array}$ \\
\hline $\begin{array}{l}\mathrm{Lw} \\
\mathrm{Lb} \\
\mathrm{Mm}\end{array}$ & 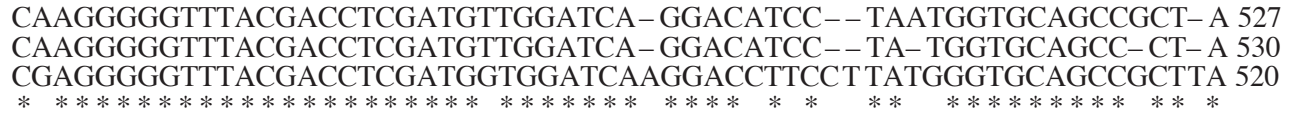 \\
\hline $\begin{array}{l}\mathrm{Lw} \\
\mathrm{Lb} \\
\mathrm{Mm}\end{array}$ & $\begin{array}{l}\text { TTAAGGG-TTCGTTTGTTCA-CGATTAA-GTCCTAAGTGATGGG } 568 \\
\text { T--AAGG- TTCGTTTGT-CA-CGATTAA-GTCT--AGTGTTGGG } 566 \\
\text { TTGAGGGGTTCGTTTGTTCAACGATTAAAGTCCTACGTGATCTG } 564\end{array}$ \\
\hline
\end{tabular}

TABLE 4. - Comparison of PCR-SSCP and PCR-fragment size determination methods for identification of formalin-fixed fish eggs. Costs: actual costs (approx.) in euros, at the University of Oviedo (Spain) in 2005. Time required from the end of the PCR until visualisation of the PCR product. Success: proportion of formalin-fixed eggs successfully typed, in percent. Sample sizes: 122 and 220 for PCR-SSCP and PCR-fragment size determination, respectively.

Feature

PCR-SSCP

PCR-fragment size determination

Equipment required

Equipment cost

Maintenance costs of the equipment, per year Analysis cost (64 samples)

Time required (64 samples)

Success

Technical expertise
Dual gel vertical unit of electrophoresis $+$

Power supplier

$€ 1,200$

$+$

$€ 1,000$
None

None

$5 \mathrm{~h}$

$95 \%$

Basic molecular biology
Automated sequencer (i.e. Genetic Analyser)

Computer with software (i.e. GenMapper) $€ 300,000$

$+$

$€ 6,000$

$€ 6,000$

$€ 230.4$

3 h 45 min (16 capillaries) $85 \% *$

Specialised technician 


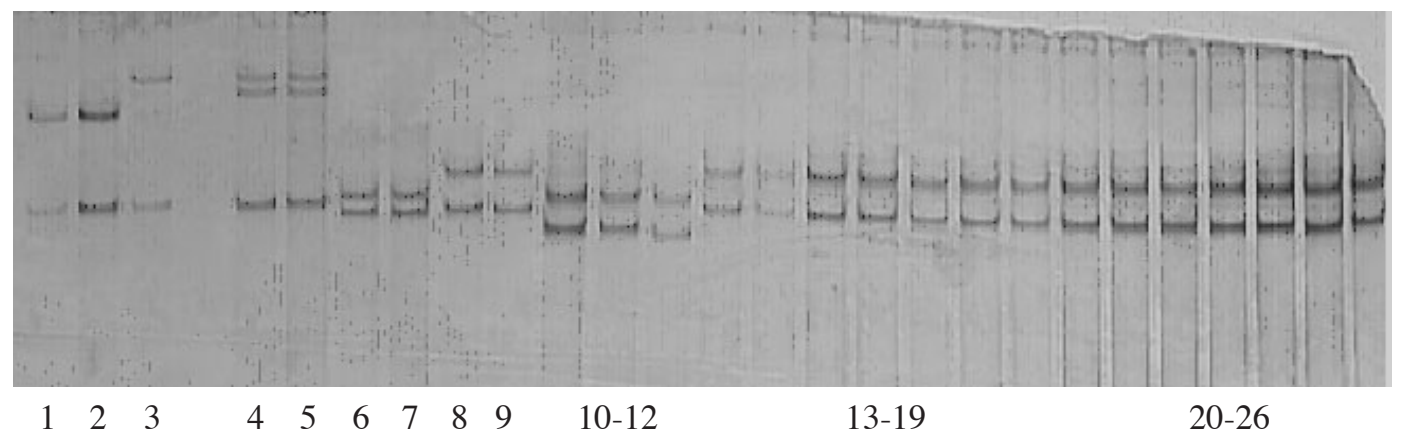

FIG. 4. - Acrylamide gel showing the SSCP-PCR pattern found for Lepidorhombus whiffiagonis eggs fixed in ethanol (13-19) or in 4\% formaldehyde (20-26). Control adults: 1-5, Lepidorhombus boscii (variants D, E and F); 6-7, Mediterranean L. whiffiagonis (variant C); 8-9, Atlantic L. whiffiagonis (variant B); 10-12, Merluccius merluccius (variant A). Both ethanol-fixed and formaldehyde-fixed megrim eggs presented the variant $\mathrm{B}$.

required for SSCP was considerably simpler and cheaper than that required for typing eggs employing PCR + fragment size determination in automated sequencer. Second, the technical expertise required for detecting SSCP in acrylamide gels consisted of basic skills in molecular biology (PCR, preparing and loading acrylamide gels, basic silver staining protocols), whereas an expert technician is required to manage an automated sequencing machine. Third, costs of PCR-SSCP were much lower for the above reasons. Higher success of genetic typing for formalin-fixed eggs was obtained by the SSCP method than by the PCR + fragment size determination protocol (95 and $85 \%$ respectively). The time required for completing each protocol was similar.

\section{DISCUSSION}

Species-specific 16S rRNA gene SSCP patterns were obtained for several fish species, allowing identification of the eggs of these species in plankton samples (Table 2, Fig. 2). Macrorhamphosus scolopax, Lepidorhombus whiffiagonis, Trachurus trachurus, Scomber scombrus and Merluccius merluccius eggs were easily identified in a sample of ichthyoplankton. However, this marker provided similar SSCP patterns for some Gadoid species; for example, Merlangius merlangus and Gadus morhua exhibited bands that were practically indistinguishable in $8 \%$ acrylamide gels (Fig. 2A). For some species this problem can be solved with some minor technical modifications. For example, Pollachius pollachius and $P$. virens provided almost identical SSCP patterns in $8 \%$ acrylamide gels (Fig. 2A) but were easily distinguishable in $12 \%$ acrylamide gels (Fig. 2B). On the other hand, some eggs obtained from plankton samples (Table 2) provided unknown
SSCP patterns, indicating that they belonged to species not considered in the present work. Standardisation of the technique should include clear descriptions of SSCP patterns obtained for each commercial species at different acrylamide concentrations. It is also necessary to consider the need to keep standard DNA samples of the target species to be included as references in routine gels. However, a different species from those analysed here that is present in the plankton tows may have the same banding pattern as one in the analysis. This problem is impossible to solve, with this or any other method, unless all fish species present in a given marine region are analysed. Ideally, if all species are sampled it would be possible to find a molecular marker (or a combination of different markers) that is useful for identifying all species in this gene or in other genome regions with different degrees of conservation.

The SSCP patterns obtained for the three species with morphologically similar eggs (European hake and megrims) were species-specific. No one variant was shared by two species. The large number of adults analysed, 80-100, obtained from different marine areas of the distribution of each species, confirms the universal validity of the marker here described. Species-specific fragment size differences within the 16S rRNA gene had been already reported for these three species (Pérez et al., 2005). However, fragment size determination in degraded DNA samples, such as formaldehyde-fixed eggs, is not easy (Díaz-Viloria et al., 2005). In the case described by Pérez et al. (2005) it required fluorescence detection in an automated sequencer, because agarose gels were not sensitive enough for detecting amplification bands. The SSCP method offers some advantages with respect to fragment size determination (Table 4). Although a little more time-consum- 
ing than automated fragment size identification, it is simpler and cheaper. It does not depend on sophisticated equipment and specialised expertise is not necessary for egg typing. This method is sensitive but inexpensive and rapid (Sunnucks et al., 2000), three characteristics that represent an improvement with respect to previously described genotyping methods. It could be considered for routine surveys of large sample sizes.

SSCP methodology has been applied for species identification in aphids (Wilson et al., 1999), but its utility in formaldehyde-preserved tissues is reported here for the first time. The eggs analysed in this study had been preserved in formalin for one year. The PCR-SSCP patterns of formaldehyde-fixed eggs were all reproducible, although some authors (O'Leary et al., 1994; de Giorgi et al., 1994; and Díaz-Viloria et al., 2005) claimed the reduction of reliability of PCR when tissues are preserved in formaldehyde. The whole 16S rRNA gene, more than 500 bp long, was amplified in more than $90 \%$ formaldehyde-fixed eggs. The great length of the amplified fragment may represent an advantage for employing this methodology in formalin-fixed tissues. Although the method can be considered robust enough for analysing fragments as large as $775 \mathrm{bp}$ (Sunnucks et al., 2000), only $80 \%$ of single base pair differences can be resolved by the SSCP technique for $400 \mathrm{bp}$ fragments (Girman, 1996). Thus, single-nucleotide changes eventually induced by formalin exposure would probably produce differences in SSCP patterns for short sequences but, as occurred in the present case, would remain undetected in longer fragments, preserving species-specificity.

Different SSCP patterns were found within Lepidorhombus species. The existence of intraspecific variants for Lepidorhombus whiffiagonis and $L$. boscii may be used for detecting genetic variation that can be applied for population studies in these two species, as described for other taxa (revision in Sunnucks et al., 2000). Moreover, 8-nucleotide-long insertion/deletion in Mediterranean L. whiffiagonis samples suggests the existence of a subspecies in this region (García-Vázquez et al., 2006). Further studies will be carried out employing this approach to study the population structure of these species, which is unknown at the present.

The SSCP method should be further developed for ichthyoplankton identification. For example, species-specific single-nucleotide variation, impos- sible to detect by this method in a sequence more than 500 bp long like the 16S rRNA gene, can be detected in shorter sequences (Sunnucks et al., 2000). If the method is considered for routine surveys, SSCP patterns of marker sequences should be obtained and characterised for all fish species whose eggs are present in plankton in a given marine area. With these relatively simple developments, the SSCP technique appears to be promising for ichthyoplankton analysis due to its simplicity, low cost and easy handling.

\section{ACKNOWLEDGEMENTS}

We are indebted to Dr Ignacio Sobrino (IEO Cádiz, Spain) for kindly providing adult samples. We wish to thank M. Santurtun and J. Ruiz for their collaboration in obtaining fertilised eggs. Ivan G. Pola (Universidad de Oviedo) collaborated in laboratory tasks. This work was supported by the European Contract MARINEGGS QLK5-CT199901157.

\section{REFERENCES}

Congdom, B.C., J.F. Piatt, K. Martin and V.L. Friesen. - 2000 Mechanisms of population differentiation in marbled murrelets: historical vs contemporary evolutionary processes. Evolution, 54: 974-986.

D’Urso, F., A. Sambade, A. Moya, J. Guerri and P. Moreno. - 2003. Variation of haplotype distributions of two genomic regions of Citrus tristeza virus populations from eastern Spain. Mol. Ecol., 12: 517-526.

De Giorgi, C., M.F. Sialer and F. Lamberti. - 1994. Formaldehydeinduced infidelity in PCR-amplified DNA fragments. Mol. Cell. Probes, 8: 459-462.

De Salle, R. and V.J. Birstein. - 1996. PCR identification of black caviar. Nature, 381: 197-198.

Díaz-Viloria, N., L. Sánchez-Velasco and R. Pérez-Enríquez. 2005. Inhibition of DNA amplification in marine fish larvae preserved in formalin. J. Plankton Res., 27: 787-792.

Estoup, E., C.R. Lagiader, E. Perrot and D. Chourrout. - 1996. Rapid one-tube extraction for reliable PCR detection of fish polymorphic markers and transgenes. Mol. Mar. Biol. Biotechnol., 5: 295-298.

Feral, J.P. - 2002. How useful are the genetic markers in attempts to understand and manage marine biodiversity? J. Exp. Mar. Biol. Ecol., 268: 121-145.

Girman, D. - 1996. The use of PCR-based single-stranded conformation polymorphism analyses (SSCP-PCR) in conservation genetics. In: T.B. Smith and R.K. Wayne (eds.), Molecular Genetic Approaches in Conservation, pp. 167-182. Oxford University Press, Oxford.

García-Vázquez, E., J.I. Izquierdo and J. Pérez. - 2006. Genetic variation at ribosomal genes supports the existence of two different European subspecies in the megrim Lepidorhombus whiffiagonis. J. Sea Res., in press.

Hall, T. A. - 1999. BioEdit: a user-friendly biological sequence alignment editor and analysis program for Windows 95/98/NT. Nucl. Acids. Symp. Ser., 41: 95-98.

Hayashi, K. and D.W. Yandell. - 1993. How sensitive is PCR- 
SSCP? Hum Mutat. 2: 338-346.

Hedrick, P.W., K.M. Parker, E.L. Miller and P.S. Miller. - 1999. Major histocompatibility complex variation in the endangered Przewalski's horse. Genetics, 152: 1701-1710.

Medeiros-Bergen, D.E., R.R. Olson, J.A. Conroy and T.D. Kocher. 1995. Distribution of holothurian larvae determined by speciesspecific genetic probes. Limnol. Oceanogr., 40: 1225-1235.

Moser, H.G., D.M. Richards, M.P. Cohen, M.P. Fahay, A.W Kendall and S.L. Richardson. - 1984. Ontogeny and systematics of fishes. Am. Soc. Ichthyol. Herpetol. Spec. Publ., 1.

O'Leary, J.J., G. Browne, R.J. Landers, M. Crowley, I. Bailey, J.T. Stret, M. Pollock, M.J. Murphy, M.I. Jonhson, F.A. Lewis, O. Mohamdee, C. Cullinane and C.T. Doyle. - 1994. The importance of fixation procedures on DNA template and its suitability for solution-phase polymerase chain reaction and PCR in situ hybridisation. Histochem. J., 26: 337-346.

Palumbi, S. and P. Cipriano. - 1998. Species identification using genetic tools: The value of nuclear and mitochondrial gene sequences in whale conservation. J. Hered., 89: 459-464

Palumbi, S., A. Martin, S. Romano, W.O. McMillan, L. Stice and G. Grabowski. - 1991. The simple fool's guide to PCR. V. 2.0. Spec. Publ. University of Hawaii, Department of Zoology \& Kewalo Marin Laboratory, Honolulu, HI.

Pérez, J. and E. García-Vázquez. - 2004. Genetic identification of nine hake species for detection of commercial fraud. J. Food Protect., 67: 2792-2796.

Pérez, J., P. Álvarez, J.L. Martínez and E. García-Vázquez.- 2005. Genetic identification of hake and megrim eggs in formaldehyde-fixed plankton samples. ICES J. Mar. Sci., 62: 908-914.

Schmalenberger, A. and C.C. Tebbe. -2003 . Bacterial diversity in maize rhizospheres: conclusions on the use of genetic profiles based on PCR-amplified partial small subunit rRNA genes in ecological studies. Mol. Ecol., 12: 251-262.

Shao, K.T., K.C. Chen and J.H. Wu. - 2002. Identification of marine fish eggs in Taiwan using light microscopy, scanning electric microscopy and mtDNA sequencing. Mar. Freshw.
Res. 53: 355-365.

Small, M.P. and E.M. Gosling. - 2000. Genetic structure and relationships in the snail species complex Littorina arcana Hannaford Ellis, L. compressa Jeffreys and L. saxatilis (Olivi) in the British Isles using SSCPs of cytochrome-b fragments. Heredity, 84: 692-701.

Sunnucks, P., A. C.C. Wilson, L.B. Beheregaray, K. Zenger, J. French and A.C. Taylor. - 2000. SSCP is not so difficult: the application and utility of single-stranded conformation polymorphism in evolutionary biology and molecular ecology. Mol. Ecol., 9: 1699-1710.

Sweijd, N.A., R.C. K. Bowie, B.S. Evans and A.L. Lopata. - 2000. Molecular genetics and the management and conservation of marine organisms. Hidrobiología, 420: 153-164.

Taylor, A.C., P. Sunnucks and D.W. Cooper. - 1999. Retention of reproductive barriers and reproductive synchronisation in introduced sympatric Macropus spp. in New Zealand. Anim. Conserv., 2: 195-202.

Taylor, M.I., C. Fox, I. Rico and C. Rico. - 2002. Species-specific TaqMan probes for simultaneous identification of cod (Gadus morhua L.), haddock (Melanogrammus aeglefinus L.) and whiting (Merlangius merlangus L.). Mol. Ecol. Notes, 2: 599601.

Thompson, J.D., D.G. Higgins and T.J. Gibson. - 1994. CLUSTAL $\mathrm{W}$ : improving the sensitivity of progressive multiple sequence alignment through sequence weighting, position specific gap penalties and weight matrix choice. Nucleic Acids Res., 22: 4673-4680.

Wilson, A.C.C., P. Sunnucks and D.F. Hales. - 1999. Microevolution, low clonal diversity and genetic affinities of parthenogenetic Sitobion aphids in New Zealand. Mol. Ecol., 8: $1655-1666$.

Received October 28, 2005. Accepted March 8, 2006.

Published online September 26, 2006. 
